\title{
TO THE STATE BUILDING NORMS UKRAINE (B.2.5-28-2018) «NATURAL AND ARTIFICIAL LIGHTING»
}

Vasilenko A.B., Doctor of Architecture, Professor, abvasilenko10@gmail.com, ORCID: 0000-0002-8261-3104 Namchuk A.V., Master of Architecture and Urban Planning, aleks.namchuk@gmail.com, ORCID: 0000-0001-5185-8072 Odessa State Academy of Civil Engineering and Architecture

\begin{abstract}
In the present study, materials were proposed for the editorial board supplement of Ukraine (B.2.5-28-2018) «Natural and artificial lighting». Work on the addition of instructions has not finished today. Theoretical materials are associated with calculations of the lighting of the inner spaces of architectural objects. Proposals are theoretical. Character takes into account the impact on energy efficiency of buildings and structures. In the manual «Natural and artificial lighting» there is a discomfort indicator $M$. The discomfort rate $M$ is the evaluation criterion. Uncomfortable luster causes discomfort with an uneven distribution of brightness in the field of view of a person. As a result, this study analyzed and determined analytically the additions to the application materials of the instructions of Ukraine (B.2.5-28-2018) «Natural and artificial lighting» (comfort indicator $C$, quality criteria for natural lighting). The comfort index $C$ is criteria for evaluating comfort shine. The criteria for the quality of natural lighting includes the elimination of visual discomfort; uneven distribution of light fluxes in the room; contrast of light; spatial illumination; light vector. Improving and complementing lighting today is the foundation. Regulatory documents affect problem solving: ensuring the quality of the architectural environment in ecological and demographic systems; psychological comfort; the effectiveness of the use of the aesthetic potential of natural and artificial light; innovative lighting technologies of domestic and world production.
\end{abstract}

Keywords: visual comfort, comfort index, criteria for the quality of natural light, distribution of brightness in the surrounding space, visual discomfort, uneven distribution of light streams, contrast of illumination, light vector, spatial illumination.

Introduction. Natural and artificial lighting always meets comfortable, aesthetic, sanitary, hygienic, and economic requirements. The modern market offers new types of artificial lighting, new transparent materials for window fillings. The main priority and scientific direction for creating ecological architecture is the urban and ecological approach of forming a light environment for human life and activity. There are significant changes in climatic, insolation and other resources vital for human life and activities.

There are various anthropogenic factors. The transparency of the atmosphere due to the growth of cities and industry is reduced. Light is a natural substance. Light is a modern means of creating an expressive architectural composition. Light provides favorable conditions for the interaction of man and the environment. The sunlight manifests the form of an architectural object. Light creates a light image. At night, architecture becomes a source of artificial lighting. Used in architectural designing of technical means, innovative light technologies, solar energy for creating an aesthetic image and solving design problems.

Comfortable light environment in designing largely depends on the choice of interior and exterior lighting architectural objects. Supplement to the annexes of the state building norms of Ukraine on lighting (the index of comfort C, visual comfort, criteria of the quality of natural light) is an actual task.

Thus, the problem of comfortable light environment in architecture at the center of social attention and major issues in the field of ecology, architecture and urban planning. 
Analysis of recent research. The problem of determining and creating a comfortable light environment in the internal and external spaces of buildings and structures is at the center of social attention and in the field of urgent issues of ecology, architecture and urban planning.

The main researches in the field of the theory of solar radiation and calculations of insolation in construction are the works: N. Danzig, V. Drozdov, B. Dunaev, O. Ershov, E. Pugachev, S. Skryl, F. Erism. Among the foreign authors should be distinguished works: R. Hopkinson, K. Cowleson, E. Niiman, A. Olghei, P. Peterbridge, G. Playzhel, H. Rong, L. Holm.

Scientific research on the role of a comfortable light environment in modern architecture was reflected in works - M. Gusev, N. Danzig, V. Drozdov, B. Dunaev, O. Ershov, N. Kireev, D. Lazarev, S. Skryl, S. Langer, M. Heidegger, M. Merlot-Ponty.

Purpose and tasks of the research. The study aims to determine application state building codes «Natural and artificial lighting» additions.

In developing regulations and improvement of natural and artificial lighting defined tasks:

1. Calculate the index of comfort of the light environment.

2. Determine the criteria for the quality of natural light:

- Distribution of brightness in the surrounding space.

- Elimination of visual discomfort.

- Uneven distribution of light streams in the room.

- Contrast of illumination.

- Spatial illumination.

- Light vector.

Methods of research. Professor of the Kiev Building University Oleg Sergeychuk in the article «Requirements of the European Union - the basis of the development of a set of normative documents on natural and artificial lighting» gave in details and provided suggestions for improving the structure of regulatory documents. These are calculations in the design of lighting systems in construction and alignment with the applicable standards.

The work was undertaken to improve the regulatory framework for designing lighting systems for buildings. An amendment to the state building codes «Artificial and natural light» was approved, to the state standard of Ukraine «Guidelines for the calculation of insolation of objects of civil purpose». Now work on the development of a new edition of the Ukrainian building regulations is underway [1].

At the present stage, normative documents on natural and artificial lighting include: state standards: «Calculation and design of lateral natural light»; "Calculation and design of rectangular, trapezoid and tail lights»; "Calculation and design of antiaircraft and shaft lanterns»; "Calculation and design of light guides»; «Calculation and Design of Combined Natural Lighting Systems»; «Calculation and designing of sunscreen systems»; «Calculation of economic and environmental indicators of natural lighting systems»; «Calculation of quantitative and qualitative indicators of artificial lighting»; «Designing artificial lighting systems for industrial buildings»; «Designing artificial lighting systems for residential and public buildings»; «Designing artificial lighting systems for enterprise sites»; «Designing artificial lighting systems for urban and rural settlements»; «Calculation of economic and environmental indicators of artificial lighting systems»; «Calculation and design of gel lighting systems»; «Calculation and design of combined lighting systems»; «Installation and maintenance of natural lighting systems»; «Installation and maintenance of artificial lighting systems».

Today, the issue of improving lighting standards is being discussed. These are rules like:

- optimization of the area of light cavities; harmonization of sanitary and hygienic requirements with economic ones; introduction of fiber optics for the illumination of sunlight without windows; introduction of accumulating systems for artificial lighting; implementation of redistribution of light streams; the introduction of protective devices from the Sun [2].

An extended and amended version of the rules was published (DIN EN 12464-1, Ausgabe 2003-03. Lichtund Beleuchtung - Beleuchtung von Arbeitsstätten. - Teil 1: Arbeitsstättenin Innenräumen; Deutsche Fassung EN 12464-1:2002) [3].The standards were developed by the Technical Committee No. 169 of the European Commission for the regulation of electrical engineering (CEN/CENELEC TC 169). Detailed national standards have been replaced by a single 
document. The document gives recommendations for lighting local areas. There are many specialized national rules and regulations in European countries [4]. International Commission on Standardization (ISO) on the basis of [5] has adopted international standards for indoor lighting ISO 8995:2002. The above norms act as national in the countries of eastern Europe [6].

The proposed theoretical materials should take into account the impact on the energy efficiency of buildings. Environmental criteria in architecture are criteria for functional comfort. An integral criterion or functional comfort is considered as a functional state. Functional comfort includes two basic components - psychological and psychophysiological.

Creation of a light comfortable environment for human life and self-realization is possible. Comfortable light environment is a system of providing functional comfort in the interior plus aesthetic comfort in the exterior and interior.

Scientific research on the role of a comfortable light environment in modern architecture was reflected in the works - M. Guseva, N. Danziga, V. Drozdova, B. Dunaeva, O. Ershov, N. Kireeva, D. Lazareva, E. Pugacheva, S. Skryla, F. Erisma, S. Langera, M. Heideggeroma, M. Merlot-Ponty.

Economically beneficial systems for redistribution of light flux. They have special window holes. The light is transmitted further from the window (deep into the rooms). This raises the uniformity of the illumination and increases the size of the room [1,7].

Method of calculation of natural light [8] was perfected in Changes No. 2 to state building regulations. Today, European architects use several computer methods to calculate the illumination $[9,10]$.

Research results. Discomfort rate. Annex «A» of the State Building Regulations «Natural and Artificial Lighting» has an indicator of discomfort $\mathrm{M}$. The discomfort index $\mathrm{M}$ is a criterion for evaluating uncomfortable brilliance. Which causes unpleasant sensations in the uneven distribution of brightness in the field of view. Uncomfortable brilliance is expressed by the formula. Which is recommended to be transformed as follows:

$$
M=\frac{L_{c} \cdot \omega^{0,5}}{\varphi_{0} \cdot L_{\text {ад }}^{0,5}} \rightarrow \min ,
$$

where $L_{c}$ - is the brightness of the sparkling source, $\mathrm{cd} / \mathrm{m}^{2} ; \omega$ - angular size of the sparkling source, erased; $\varphi_{o}-$ position of the sparkling source relative to the line of sight; $L_{\text {ад }}-$ is the brightness of adaptation, $\mathrm{cd} / \mathrm{m}^{2}$.

When designing an index of discomfort is calculated by the engineering method.

The index of comfort $C$, visual comfort. The index of comfort $C$, visual comfort, criteria for the quality of natural light in state building regulations today are completely absent.

Therefore, the main task in the study was to improve the calculation of comfort index $C$, to determine visual comfort, criteria for the quality of natural light.

Diagram for finding a zone of discomfort [6] makes it possible to find the zone of comfort of the light environment.

The indicator of comfort $C$ [11] is a criterion for assessing the comfort of brilliance. This creates a favorable light environment in the interior or exterior. The index of comfort creates the optimal choice of lighting parameters, and is expressed by the formula [5]:

$$
C=T_{c}^{2}+E_{m}-\sqrt{T_{C}},
$$

where: $T_{c}$ - is the color temperature of the radiator (black body temperature Planca);

$E_{m}$ - free lightness factor $\left(E_{m}=8,25,130 \ldots\right.$ - diagram for finding the comfort zone $)$

$A_{1}$ - curve of the zone of discomfort with insufficient light $\left(A_{1}=\sqrt{T c}\right)$;

$A_{2}$ - the curve of the border of the zone of discomfort at a highlight $\left(A_{2}=T_{c}^{2}+E_{m}\right)$;

$A_{2}-A_{1}-$ comfortable interval of illumination (Fig. 1.).

Dependency of brilliance $\varphi_{o}$ is expressed for the natural light by the formula: 


$$
\varphi_{0}=\frac{L_{H} \omega^{0,8}}{L_{a}{ }^{1}} P,
$$

where: $\varphi_{\mathrm{o}}$-index of the brilliant source position relative to the line of sight;

$L_{H}$ - brightness of the sky, Nt;

$\omega$ - angular size of the source, ster;

$L^{1}{ }_{a}$ - brightness of the field of adaptation;

$P$ - position index.

Vision comfort - a favorable light environment in the interior. Vision comfort creates the optimal choice of lighting options.

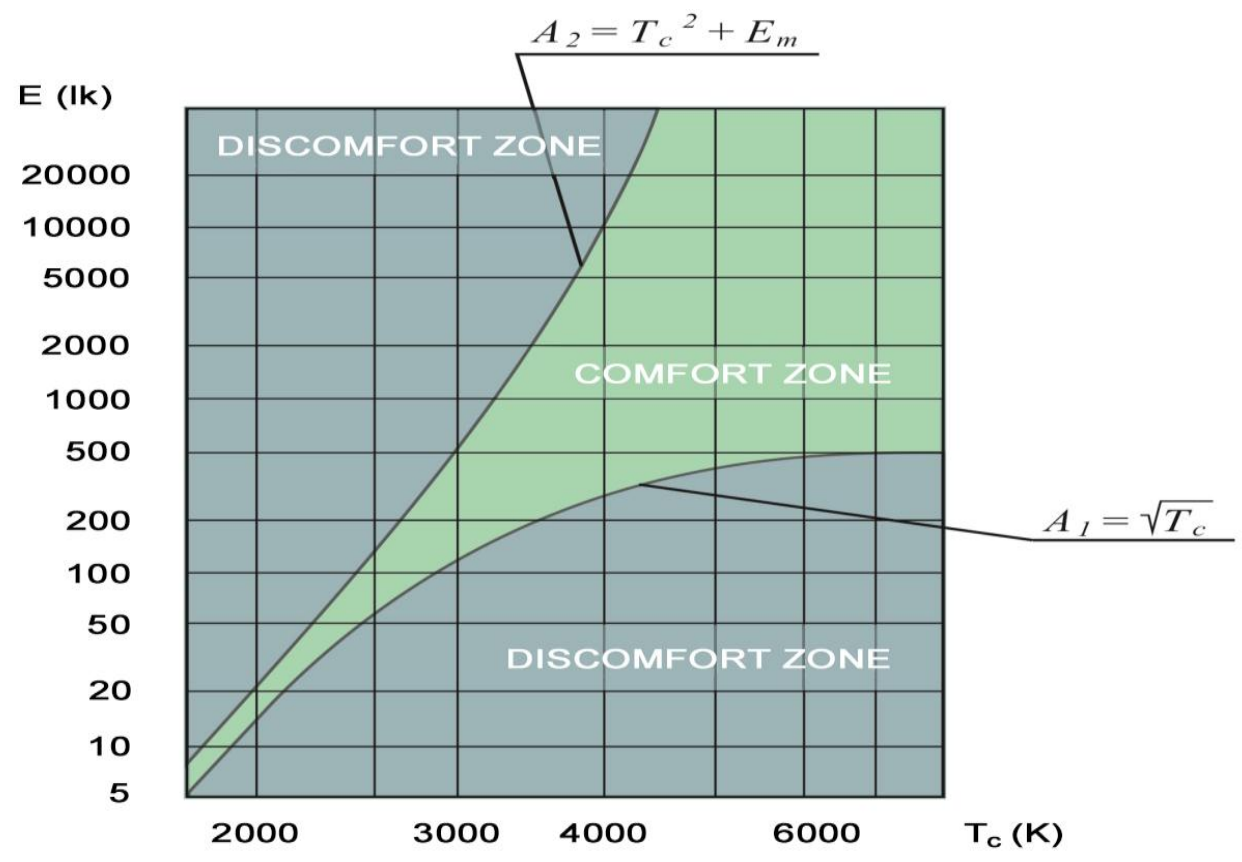

Fig. 1. Diagram for finding the comfort zone

The comfortable interval increases with an increase in the color temperature of the light source (table 1).

Table 1 - Table for finding the comfort zone

\begin{tabular}{|c|c|c|}
\hline$T_{c}(K)$ & $E_{1}$ & $E_{2}$ \\
\hline 1500 & 5 & 8 \\
\hline 2000 & 15 & 25 \\
\hline 2500 & 50 & 130 \\
\hline 3000 & 125 & 500 \\
\hline 4000 & 300 & 8000 \\
\hline
\end{tabular}

Criteria for the quality of natural light:

1. Distribution of brightness in the surrounding space.

When choosing the distribution of brightness, it is necessary to proceed from the distribution, which psychologically combines the space of the interior with nature. The reference when choosing the brightness of the ceiling, walls and floor in the rooms is the ratio of numbers Fibonachi 5:3:2.

$$
\begin{aligned}
& L_{c b}=v_{1} E_{a v}, \\
& L_{b w}=v_{2} E_{a v},
\end{aligned}
$$




$$
L_{b f}=\frac{1}{f} \rho_{n} E_{a v}
$$

where: $L_{c b}-$ the brightness of the ceiling;

$L_{b w}-$ the brightness of the walls;

$L_{b f}-$ the brightness of the floor;

$v_{1}$ - relative brightness of the ceiling;

$L_{b w}$ - relative brightness of walls;

$E_{a v}$-average illumination of the conditional horizontal plane at the level of $0.8 \mathrm{~m}$ from the floor;

$\rho_{n}$ - coefficient of the room floor reflection.

2. Removal of visual discomfort.

Eliminate visual discomfort when you hit the field of direct sunlight by limiting glare. The criterion for assessing blindness in the day is the index of the position of a brilliant source relative to the line of sight $\left(\varphi_{o}\right)$, which depends on the brightness of the sky $\left(L_{n}\right)$, the angular size of the sparkling source $(\omega)$, the position index $(P)$. Characterized by: the position of a person in relation to the surface of the window, the conditions of adaptation in the room. Determined by the average brightness of the room $\left(L_{a}\right)$.

3. Uneven distribution of light streams in the room.

The premises are divided into two groups:

- Group 1 is a room that requires uniform illumination of the working surface.

- Group 2 is a space in which the requirements for unevenness of illumination are determined by the need to distinguish the subject under consideration by the adaptation of the eye.

4. Contrast of illumination is characterized by the ratio of total illumination to illumination created by scattered light as a result of multiple reflections from the interior surfaces of the room.

The contrast of the natural light of the premises depends on the ratio of light to the direct light penetrating through the light slits of windows or lanterns to diffuse light reflected by the light from the interior surfaces of the room.

The criterion for evaluating the contrast of indoor lighting can be the ratio between direct sunlight and diffuse light.

The value of the diffuse component of natural light $\left(E_{n}\right)$ is determined by the formula:

$$
E_{n}=\frac{8 \pi}{3} \cdot \frac{L_{z}}{1+\cos ^{2} \cdot z_{c}},
$$

where: $L_{z}-$ is the brightness of the sky in the zenith, $\mathrm{cd} / \mathrm{m}^{2}$;

$z_{c}$ - height of standing of the Sun, degrees.

The ratio between the illuminations created by direct sunlight $\left(E_{n}\right)$ in the first approximation depends only on the geographical latitude of the terrain.

5. Spatial illumination - characterized by the saturation of light at this point of space, regardless of the direction of the light flux.

6. The light vector indicates the dominant direction of the incident light flux.

Conclusion. As a result of the study, additions were made to the materials of the annexes of the state building codes «Natural and artificial lighting». During the development of normative documents and the improvement of natural and artificial lighting systems, the following tasks were solved:

1. Proposed calculation of the comfort indicator of the light environment $\left(C=\left(T_{c}^{2}+E_{m}\right)-\sqrt{T_{C}}\right)$.

2. The criteria for the quality of natural lighting are determined: distribution of brightness in the surrounding space; elimination of visual discomfort; uneven distribution of light streams in the room; contrast of illumination; spatial illumination; light vector.

According to the authors above mentioned additions can be made for discussing to the developers of the annexes of the state building codes of Ukraine (V.2.5-28-2018) "Natural and artificial lighting".

Improvements and supplements to regulatory documents on lighting today are the main thing 
that determines the solution to the problems of providing a quality architectural environment, psychological comfort for people's lives, effective use of the aesthetic potential of natural light and innovative light technologies of domestic and world production.

\title{
References
}

[1] O. Sergejchuk, "The requirements of EU norms are the basis for developing a set of normative documents on natural and artificial lighting", Modern problems of technical regulation in construction: a collection of scientific works, K.: KNUBA, vol. 1, pp. 79-85, 2015.

[2] O. Sergejchuk, "Proposals for the development of a set of regulatory documents on lighting", Building constructions: interdepartmental scientific and technical collection of scientific works, K.: DPNDIBK, vol. 77, pp. 288-292, 2013.

[3] DIN EN 12464-1, Ausgabe 2003-03. Lichtund Beleuchtung - Beleuchtung von Arbeitsstätten. - Teil 1: Arbeitsstättenin Innenräumen; Deutsche Fassung EN 12464-1:2002.

[4] Baunetz wissen, electronic resource, URL: http://www.baunetzwissen.de/standardartikel/ Tageslicht_KuenstlichesLicht_167396.html

[5] DIN EN 12464-2, Ausgabe 2007-10. Lichtund Beleuchtung - Beleuchtung von Arbeitsstätten - Teil 2: Arbeitsplätzeim Freien; Deutsche Fassung EN 12464-2:2007.

[6] A. Luizov, Eye and light, L.: Energoatomizdat. Leningrad. otdelenie, 1983.

[7] J.-L. Scartezzini, \& G. Courret, "Anidolic Daylighting Systems", Solar Energy, vol. 73, no. 2, pp. 123-135, 2002.

[8] A. Daniluk, Calculation of natural room lighting, M.: GISL, p. 137, 1941.

[9] What is RADIANCE, electronic resource, URL: http://radsite.lbl.gov/radiance/

[10] Velux Day Light Visualizer, electronic resource, URL: http://www.velux.ru/professionals /for architects/daylight-visualizer.

[11] State building standards B.2.5-28-2018 «Artificial and natural lighting». K.: 2018.

\section{ДО ДЕРЖАВНИХ БУДІВЕЛЬНИХ НОРМ УКРАЇНИ (В.2.5-28-2018) «ПРИРОДНЕ І ШТУЧНЕ ОСВІТЛЕННЯ»}

\author{
Василенко О.Б., д.арх., професор, \\ abvasilenko10@gmail.com, ORCID: 0000-0002-8261-3104 \\ Намчук О.B., магістр архітектури та містобудування \\ aleks.namchuk@gmail.com, ORCID: 0000-0001-5185-8072 \\ Одеська державна академія будівництва та архітектури
}

\begin{abstract}
Анотація. У цьому дослідженні запропоновані матеріали до редакції доповнення Державних будівельних норм України (В.2.5-28-2018) «Природне і штучне освітлення». Робота над доповненням будівельних норм сьогодні не закінчена. Теоретичні матеріали пов'язані 3 розрахунками освітлення внутрішніх просторів архітектурних об'єктів. Пропозиції носять теоретичний характер, який враховує вплив на енергетичну ефективність будівель і споруд. У додатках державних будівельних норм України «Природне і штучне освітлення» має місце показник дискомфорту $M$, який є критерієм оцінки некомфортноїблискучості, що викликає неприємні відчуття при нерівномірному розподілу яскравості в полі зору людини. Вибір зони комфортного освітлення залежить від колірної температури джерела світла. Норми освітленості для джерел світла 3 колірною температурою від 2700 К до 6000 К пов'язані з розрахункової зоною комфорту згідно номограми Крюітгофа. Розрахункова зона комфорту збільшується зі зростанням температури кольору. Нормована середня освітленість залежить від колірної температури. В результаті в даному дослідженні були проаналізовані і визначені аналітичним способом доповнення до матеріалів додатків Державних будівельних норм України (В.2.5-282018) «Природне і штучне освітлення» (показник комфорту $C$, критерії якості природного освітлення). Показник комфорту $C \in$ критерієм оцінки комфортної блискучості. До критеріїв якості природного освітлення відносяться: усунення зорового дискомфорту; нерівномірність
\end{abstract}


розподілу світлових потоків у внутрішніх просторах; контрастність освітленості; просторова освітленість; світловий вектор. Удосконалення і доповнення нормативних документів щодо висвітлення сьогодні $\epsilon$ основною ланцюгом, від якого залежить вирішення проблем забезпечення якості архітектурного середовища в екологічних і демографічних системах, психологічного комфорту, ефективного використання естетичного потенціалу природного i штучного світла, інноваційних світлових технологій вітчизняного і світового виробництва.

Ключові слова: зоровий комфорт, показник комфорту, критеріїв якості природного освітлення, розподіл яскравості в навколишньому просторі, зоровий дискомфорт, нерівномірність розподілу світлових потоків, контрастність освітленості, світловий вектор, просторова освітленість.

\title{
К СТРОИТЕЛЬНЫМ НОРМАМ И ПРАВИЛАМ УКРАИНЫ (В.2.5-28-2018) «ЕСТЕСТВЕННОЕ И ИСКУССТВЕННОЕ ОСВЕЩЕНИЕ»
}

\author{
Василенко А.Б., д.арх., профессор, \\ abvasilenko10@gmail.com, ORCID: 0000-0002-8261-3104 \\ Намчук A.B., магистр архитектуры и градостроительства \\ aleks.namchuk@gmail.com, ORCID: 0000-0001-5185-8072 \\ Одесская государственная академия строительства и архитектуры
}

\begin{abstract}
Аннотация. В настоящем исследовании предложены материалы к редакции дополнения строительных норм и правил Украины (В.2.5-28-2018) «Естественное и искусственное освещение». Работа над дополнением строительных норм и правил сегодня не закончена. Теоретические материалы связаны с расчетами освещения внутренних пространств архитектурных объектов. Предложения носят теоретический характер, который учитывает влияние на энергетическую эффективность зданий и сооружений. В приложениях государственных строительных норм и правил Украины «Естественное и искусственное освещение» имеет место показатель дискомфорта $M$, который является критерием оценки некомфортной блёскости, вызывающий неприятные ощущения при неравномерном распределении яркости в поле зрения человека. Выбор зоны комфортного освещения зависит от цветовой температуры источника света. Нормы освещенности для источников света с цветовой температурой от 2700 К до 6000 К связаны с расчетной зоной комфорта по номограмме Крюитгофа. Расчетная зона комфорта увеличивается с ростом цветовой температуры. Нормированная средняя освещенность зависит от цветовой температуры. В результате в данном исследовании были проанализированы и определены аналитическим способом дополнения к материалам приложений государственных строительных норм и правил Украины (В.2.5-28-2018) «Естественное и искусственное освещение» (показатель комфорта $C$ и критерии качества естественного освещения). Показатель комфорта $C$ является критерием оценки комфортной блёскости. К критериям качества естественного освещения относятся: устранение зрительного дискомфорта; неравномерность распределения световых потоков в помещении; контрастность освещенности; пространственная освещенность; световой вектор. Совершенствование и дополнение нормативных документов по освещению сегодня является основным звеном, от которого зависит решение проблем обеспечения качества архитектурной среды в экологических и демографических системах, психологического комфорта, эффективного использования эстетического потенциала естественного и искусственного света, инновационных световых технологий отечественного и мирового производства.

Ключевые слова: зрительный комфорт, показатель комфорта, критериев качества естественного освещения, распределение яркости в окружающем пространстве, зрительный дискомфорт, неравномерность распределения световых потоков, контрастность освещенности, световой вектор, пространственная освещенность.
\end{abstract}

Стаття надійшла 10.05.2019 